\title{
Credit Risk Measurement Under Basel II: An Overview and Implementation Issues for Developing Countries
}

by

\section{CONSTANTINOS STEPHANOU \& JUAN CARLOS MENDOZA*}

\begin{abstract}
The objective of this paper is to provide an overview of the changes in the calculation of minimum regulatory capital requirements for credit risk that have been drafted by the Basel Committee on Banking Supervision (Basel II). Even though the revised credit capital rules represent a dramatic change compared to Basel I, it is shown that Basel II merely seeks to codify (albeit incompletely) existing good practices in bank risk measurement. However, its effective implementation in many developing countries is hindered by fundamental weaknesses in financial infrastructure that will need to be addressed as a priority.
\end{abstract}

Keywords: Bank regulation, capital adequacy, Basel II, credit risk, developing countries

World Bank Policy Research Working Paper 3556, April 2005

The Policy Research Working Paper Series disseminates the findings of work in progress to encourage the exchange of ideas about development issues. An objective of the series is to get the findings out quickly, even if the presentations are less than fully polished. The papers carry the names of the authors and should be cited accordingly. The findings, interpretations, and conclusions expressed in this paper are entirely those of the authors. They do not necessarily represent the view of the World Bank, its Executive Directors, or the countries they represent. Policy Research Working Papers are available online at http://econ.worldbank.org.

\footnotetext{
* Constantinos A. Stephanou (cstephanou@worldbank.org) is a Financial Economist in the Europe and Central Asia Region, and Juan Carlos Mendoza (jmendoza@worldbank.org) is a Senior Financial Economist in the Latin America and Caribbean Region. The authors would like to exp ress their gratitude to Fernando Montes -Negret, Augusto de la Torre, Joaquin Gutierrez, Yira Mascaro and Hela Cheikhrouhou for helpful comments and suggestions. The views expressed in this paper are those of the authors, and do not reflect the views of the World Bank, its Executive Directors, or the countries they represent.
} 


\section{Introduction}

The recent finalization of the new minimum regulatory capital requirements drafted by the Basel Committee on Banking Supervision ${ }^{1}$ (henceforth known as Basel II) has generated significant debate among academics, policy makers and industry practitioners. This interest stems both from the importance of these rules on banking systems around the world, as well as from the fact that the new rules represent a radical departure from the existing (Basel I) framework. Several different strands in the literature have recently emerged, focusing on the framework's theoretical merits, on specific parts of the Accord (e.g. operational risk, different Pillars), on the potential impact on banking systems, and on practical implementation issues ${ }^{2}$.

This paper focuses exclusively on credit risk measurement under Basel II, and is motivated by a desire to explain the new credit capital rules (widely perceived as being overtly complex) and to discuss some practical implementation problems for developing countries. In particular, the objectives of this paper are threefold:

- to describe some of the theoretical and empirical developments in credit risk measurement that have motivated and shaped the new rules

- to summarize the treatment of credit risk (particularly under Pillar 1) in Basel II

- to identify implementation issues and some policy implications for developing countries.

The paper concludes that although the revised credit capital adequacy rules represent a dramatic change compared to the Basel I framework, Basel II merely seeks to codify (albeit incompletely) existing good practices in bank risk measurement. However, its effective implementation in many developing countries is hindered by fundamental weaknesses in financial infrastructure that will need to be addressed as a priority.

The rest of this section contains a brief overview of the Basel I and II frameworks. Section 2 describes the key building blocks for measuring credit risk. Section 3 summarizes the new credit capital rules of Basel II, and Section 4 discusses practical implementation problems for developing countries and draws relevant policy implications.

\footnotetext{
${ }^{1}$ The Basel Committee on Banking Supervision is a committee comprising of senior bank supervisory authority and central bank representatives from the G-10 countries. The Committee does not possess any formal supranational supervisory authority, but it formulates (by consensus) broad supervisory standards and promotes best practices in the expectation that each country will implement them in ways most appropriate to its circumstances.

${ }^{2}$ The bibliography at the end of this paper contains some of the most important recent contributions to the literature, while reference to specific publications (where appropriate) is made throughout the text.
} 


\section{Basel I}

The Basel I Capital Accord, published in $1988^{3}$, represented a major breakthrough in the international convergence of supervisory regulations concerning capital adequacy. Its main objectives were to promote the soundness and stability of the international banking system and to ensure a level playing field for internationally active banks. This would be achieved by the imposition of minimum capital requirements for credit (including country transfer) risk, although individual supervisory authorities had discretion to build in other types of risk or apply stricter standards. Even though it was originally intended solely for internationally active banks in G-10 countries, it was eventually recognized as a global standard and adopted by over 120 countries around the world.

The framework defined the constituents of 'regulatory capital' (numerator of the solvency formula) and set the risk weights for different categories of on- and off-balance sheet exposures (denominator of the solvency formula). The risk weights, which were intentionally kept to a minimum (only five categories/buckets), reflected relative credit riskiness across different types of exposures. The minimum ratio of regulatory capital to total risk-weighted assets (RWA) was set at 8\%, of which the 'core capital' element (a more restrictive definition of eligible capital known as Tier 1 capital) would be at least 4\%. The most important amendment to the framework took place in 1996, when an additional capital charge was introduced to cover market risk in banks' trading books ${ }^{4}$. However, the basic credit risk capital measurement framework remained unchanged, although the definition of assets and capital has evolved over the years in response to financial innovation.

Although the Basel I framework helped to 'level the playing field' and to stabilize the declining trend in banks' solvency ratios, it suffered from several problems that became increasingly evident over time:

- Lack of sufficient risk differentiation for individual loans. The weights did not sufficiently differentiate credit risk by counterparty (i.e. financial strength) or loan (e.g. pledged collateral, covenants, maturity) characteristics. For example, the capital charge for all corporate exposures was the same irrespective of the borrower's actual rating. This implied that banks with the same capital adequacy ratio (CAR) could have very different risk profiles and degrees of risk exposure.

- No recognition of diversification benefits. Standard portfolio theory recognizes the risk reduction benefits attained from diversification. However, because Basel I was based on the 'building blocks' approach, there was no distinction or difference in capital treatment between a well-diversified (less risky) loan portfolio from one that is very concentrated (and hence riskier).

- Inappropriate treatment of sovereign risk. Basel I's capital treatment for sovereign exposures made little economic sense, and the mechanical application of these rules often created perverse incentives and led to the mispricing of risks. For example, lending to OECD governments became more attractive because it incurred no regulatory capital charge, even though this group included countries

\footnotetext{
${ }^{3}$ See Basel Committee on Banking Supervision (July 1988).

${ }^{4}$ See Basel Committee on Banking Supervision (January 1996).
} 
with substantially different credit ratings such as Turkey, Mexico and South Korea. Claims to the national central government also enjoyed a zero risk weight, encouraging many banks (particularly in developing countries) to ignore basic diversification principles and lend heavily to their sovereigns (directly or through state-owned enterprises), thereby reducing financial intermediation.

- Few incentives for better overall risk measurement and management. The lack of emphasis on other risk types (e.g. interest rate, operational, business) and on financial infrastructure issues (e.g. accounting, legal framework) did not provide adequate incentives to encourage complementary improvements in banks' risk governance and measurement. As a result, there was often an excessive reliance on, and a false comfort from, a high capital adequacy ratio. Subsequent experience has shown that such a ratio, by itself, is meaningless in the absence of other supporting measures.

The shortcomings of Basel $\mathrm{I}^{5}$ meant that regulatory capital ratios were increasingly becoming less meaningful as measures of true capital adequacy, particularly for larger, more complex institutions. In addition, various types of products (e.g. 364-day revolvers and 'balance sheet' securitizations) were developed primarily as a form of regulatory capital arbitrage to overcome those rules. Finally, the state of risk measurement and management evolved significantly in the last 15 years, allowing many banks to develop their own sophisticated internal economic capital models (oftentimes running parallel to regulatory capital ones) to guide business decisions. The relegation of regulatory capital measurement and reporting to primarily a compliance and public relations ${ }^{6}$ exercise also had the perverse effect of distancing bank supervisors from the actual risk assessment process and the manner in which those banks were run, since Basel I ratios in many cases formed the sole legal basis for taking supervisory action.

\section{Overview of Basel II}

Following the publication of successive rounds of proposals between 1999 and 2003, active and broad consultations with all interested parties, and related quantitative impact studies, the Basel Committee members agreed in mid-2004 on a revised capital adequacy framework (Basel II) ${ }^{7}$. The framework will be implemented in most G-10 countries as of year-end 2006, although its most advanced approaches will require one further year of impact studies or "parallel running" and will therefore be available for implementation one year later ${ }^{8}$. For banks adopting the IRB approach for credit risk or the AMA for operational risk, there will be a capital floor following implementation of the framework as an interim prudential arrangement.

\footnotetext{
${ }^{5}$ The Basel Core Principles (BCPs) for effective supervision seek to address some of these shortcomings by, for example, calling for capital requirements for interes rate and market risks. However, they lack any explicit regulatory guidelines.

${ }^{6}$ This does not mean that the actual regulatory CAR has become unimportant for bank management, regulators, rating agencies and investors, but that it provides (at least for sophisticated banks) little guidance as to the true riskiness of the business, or to the way that it is run.

${ }^{7}$ See Basel Committee on Banking Supervision (June 2004).

${ }^{8}$ Some countries (e.g. Australia) have publicly expressed their intention to adopt a single end-2007 start date instead of a 'staggered' one.
} 
The main objective of the framework is to further strengthen the soundness and stability of the international banking system via better risk management, by bringing regulatory capital requirements more in line with (and thus codifying) current bank good practices. This will be achieved by making credit capital requirements significantly more risksensitive and by introducing an operational risk capital charge. The intention is to broadly maintain the aggregate level of capital requirements ${ }^{9}$, but provide incentives to adopt the more advanced risk-sensitive approaches of the revised framework. These changes are implemented by changing the definition of Risk Weighted Assets (i.e., the denominator of the CAR) while leaving most of the other elements of Basel I unchanged, such as the focus on accounting data, the definition of eligible capital, the $8 \%$ minimum CAR requirement and the 1996 market risk amendment to the Capital Accord.

Basel II consists of a broad set of supervisory standards to improve risk management practices, which are structured along three mutually reinforcing elements or pillars:

- Pillar 1, which addresses minimum requirements for credit and operational risks

- Pillar 2, which provides guidance on the supervisory oversight process

- Pillar 3, which requires banks to publicly disclose key information on their risk profile and capitalization as a means of encouraging market discipline.

Compared to Basel I, the scope of application is broader and includes, on a fully consolidated basis, all major internationally active banks at every tier within a banking group (i.e. full sub-consolidation), as well as at the level of the group's holding company ${ }^{10}$. Supervisors also need to ensure that individual banks within the group remain adequately capitalized on a stand-alone basis. Consolidation must capture, to the greatest extent possible, all banking and relevant financial activities (both regulated and unregulated) with the exception of insurance. Significant minority investments where control does not exist, as determined by national accounting and/or regulatory practices, will either be deducted from equity or consolidated on a pro-rata basis. However, significant minority and majority investments in commercial entities that exceed certain materiality levels (subject to some national discretion) will be deducted from banks' capital.

Before describing Basel II in greater detail, it is necessary to briefly review the credit risk concepts that have been developed by leading financial institutions in the last 10-15 years and that constitute the basis of the Accord's credit risk measurement framework.

\footnotetext{
${ }^{9}$ In fact, the Committee declared its willingness to review the calibration of the framework prior to implementation and apply a scaling factor to ensure that aggregate minimum capital requirements are broadly maintained.

${ }^{10}$ This is the minimum requirement for G-10 countries. Some of these (e.g. EU members) have gone beyond this minimum and intend to extend the application of Basel II to all domestic banks and investment firms.
} 


\section{Credit Risk Building Blocks}

Credit risk has been traditionally defined as default risk, i.e. the risk of loss from a borrower/counterparty's failure to repay the amount owed (principal or interest) to the bank on a timely manner based on a previously agreed payment schedule. A more comprehensive definition would actually include value risk, i.e. the risk of loss of value from a borrower migrating to a bwer credit rating (opportunity cost of not pricing the loan correctly for its new level of risk) without having defaulted. In order to protect themselves against volatility in the level of default/value losses (as well as other types of risk), banks have adopted methodologies that allow them to quantify such risks and thereby derive the amount of capital required to support their business - what is referred to as economic capital. The building blocks of economic capital for default-related credit risk are discussed below ${ }^{11}$.

It should be noted that the calculation of economic capital takes a purely 'economic' view of the business, which often differs from the one represented by financial statements. For example, when there is a credit deterioration of the borrower, the resulting value loss is often not shown (at least immediately) in the bank's balance sheet and income statements. This is because many credit exposures are recorded on an accrual basis as opposed to market/fair value, meaning that a loss in the value of a downgraded loan is not realized until the loan actually defaults or is sold to a third party at arm's length. As a result, economic capital models that feed into risk adjusted return on capital (RAROC) performance measures ${ }^{12}$ often paint a different, more realistic and dynamic picture of a bank's profitability than what is shown in traditional financial statements.

\section{Expected Versus Unexpected Loss}

Although credit losses naturally fluctuate over time and with economic conditions, there is (ceteris paribus) a statistically measured, long-run average loss level. Assume for example that, based on historical performance, a bank has come to expect around $1 \%$ of its loans to default every year, with an average recovery rate of 50\%. In that case, the bank's expected loss (EL) for a credit portfolio of $\$ 1$ billion is $\$ 5$ million (i.e. $\$ 1$ billion $\mathrm{x}$ $1 \%$ x 50\%). As can be deduced, EL is based on three parameters:

- The likelihood that default will take place over a specified time horizon (probability of default or PD)

- The amount owned by the counterparty at the moment of default (exposure at default or EAD)

- The fraction of the exposure, net of any recoveries, which will be lost following a default event (loss given default or LGD).

\footnotetext{
11 The rest of the section discusses default risk, which is the main focus of Basel II's Pillar 1. Value risk, which necessitates a substantial modeling exercise to value each credit exposure in each possible migratory state and then probability-weigh them to arrive at the expected change in the credit's value, is not covered.

${ }^{12}$ RAROC sought to replace the traditional ROE (Return on Equity) measure by explicitly tying returns to true economic risk. This was to be achieved by incorporating the cost of such risk in the returns (i.e. the numerator of the equation) and dividing the result by economic capital (as opposed to book capital).
} 
Since PD is normally specified on a one-year basis ${ }^{13}$, the product of these three factors is the one-year EL as follows:

$$
\mathrm{EL}=\mathrm{PD} \times \mathrm{EAD} \times \mathrm{LGD}
$$

EL can be aggregated at various different levels (e.g. individual loan or entire credit portfolio), although it is typically calculated at the transaction level; it is normally mentioned either as an absolute amount or as a percentage of transaction size. It is also both customer- and facility-specific, since two different loans to the same customer can have a very different EL due to differences in EAD and/or LGD.

It is important to note that EL (or, for that matter, credit quality) does not by itself constitute risk; if losses always equalled their expected levels, then there would be no uncertainty. Instead, EL should be viewed as an anticipated "cost of doing business" and should therefore be incorporated in loan pricing and ex ante provisioning.

Credit risk, in fact, arises from variations in the actual loss levels, which give rise to the so-called unexpected loss (UL). Statistically speaking, UL is simply the standard deviation of EL (see Figure 1). As will be described later, the need for bank capital stems from the desire to cushion against loss volatility (UL) at a certain confidence level.

\section{Figure 1: Expected and Unexpected Loss}

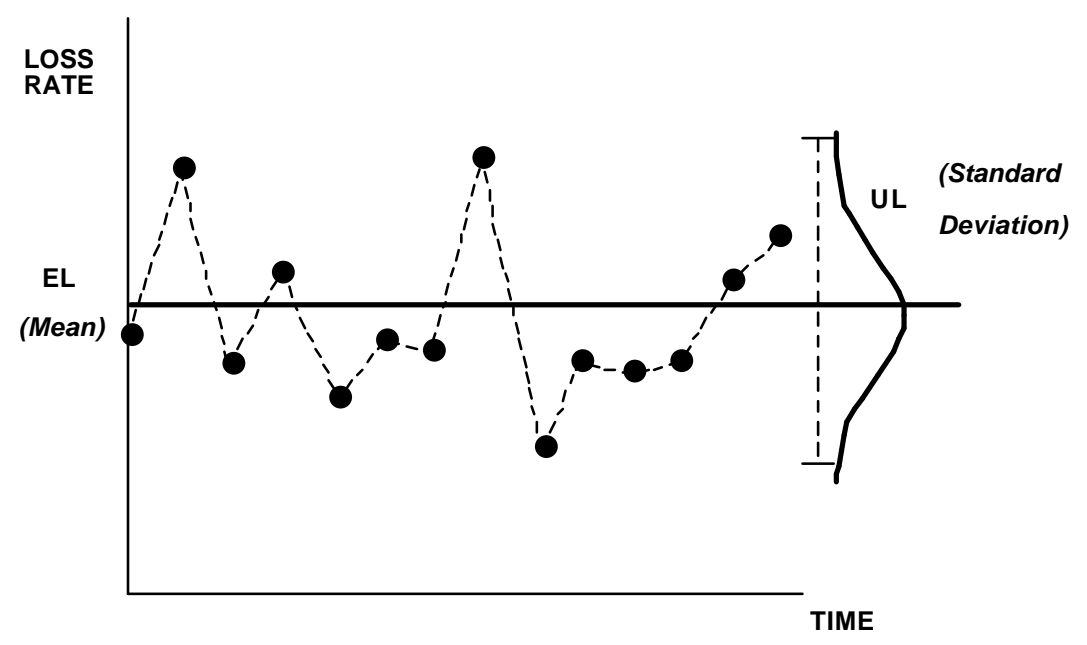

\section{Probability of Default (PD)}

Financial institutions have traditionally attempted to minimize the incidence of credit risk primarily via a loan-by-loan analysis carried out during the credit underwriting process. The foundations of a more analytical framework began in the early 1960s when the first

\footnotetext{
${ }^{13}$ Although the one-year horizon is fairly arbitrary, it is reasonable from a bank management perspective because it coincides with the typical budgeting period and because it can be considered a reasonable timeframe within which to raise new share capital to cover additional losses that might have occurred.
} 
"credit scoring" models were built to assist credit decisions for consumer loans ${ }^{14}$. Although they initially classified debtors/counterparties on default potential based only on an ordinal ranking, they were the original precursors to numerical PD estimation. By the mid-1980s, particularly with the introduction of RAROC as a performance measure, leading financial institutions began calibrating each credit score to a particular $\mathrm{PD}^{15}$ to estimate EL and ultimately economic capital.

The measurement of a PD pre-supposes the use of a definition of default that has tended to vary across credit institutions ${ }^{16}$, thereby hindering comparisons. The definitions have started to converge in recent years, while Basel II adopts a reference default definition to facilitate comparability of capital results.

Several techniques have subsequently been developed to calculate PD, which can be divided into two broad categories: empirical and market-based (also known as structural or reduced-form) models. The former use historical default rates associated with each score to identify the characteristics of defaulting counterparties, while the latter use counterparty market data (e.g. bond or credit default swap spreads, volatility of equity market value) to infer the likelihood of default.

The empirical approach uses historical default data to characterize counterparties that default. This was originally done using discriminant analysis ( $\mathrm{Z}$ scores) but more recently has been done with logit or probit regressions to define a score function $S$ of the form:

$$
S\left(x_{i}\right)=\beta_{1} x_{1}+\beta_{2} x_{2}+\ldots \beta_{n} x_{n}
$$

The vector $\mathrm{x}$ contains the relevant risk factors, which in the case of commercial counterparties may be primarily financial statement ratios and non-financial information (e.g. management quality, years in operation); for retail customers, this might include income, work history and other demographic data ${ }^{17}$. Table 1 presents a set of illustrative factors typically used in these models ${ }^{18}$.

\footnotetext{
14 This was driven by the recognition that expensive judgment-based analysis carried out for commercial loans was simply not cost-effective for mass-market retail (and eventually small business) exposures.

${ }^{15}$ Until Basel II formalized the use of PD, this concept was often called Expected Default Frequency.

16 The non-payment past due 'threshold' period triggering a default event has historically ranged from a day to a few months or even years, depending on the instrument, jurisdiction and (where it is not mandated by legal or supervisory norms) the bank involved.

${ }^{17}$ Different jurisdictions regulate differently the kind of demographic data that can be used to make lending decisions to avoid discrimination on the basis of, for example, gender or race.

18 There is no clear standard on what the appropriate predictive power of a model should be. Comparisons between models are normally carried out by drawing power curves, i.e. by sorting the customers according to their scores on the horizontal axis and generating a graph with the percentage of all the defaults in the sample covered by those customers on the vertical axis. Reasonable models should generally capture about $90 \%$ of defaults in a year from around $20 \%$ of the lower-rated scores (Kealhofer, 2003).
} 
Table 1: Typical Factors Used in Building Empirical PD Models

\begin{tabular}{|c|c|c|}
\hline Counterparty Type & Information Category & Parameter \\
\hline \multirow{4}{*}{ Corporate } & Company Type & $\begin{array}{l}\text { Industry group } \\
\text { Geography } \\
\text { Age of company } \\
\text { Total assets } \\
\text { Total sales } \\
\text { Total equity } \\
\end{array}$ \\
\hline & Financial Ratios & $\begin{array}{l}\text { Equity/Assets } \\
\text { Debt/Equity } \\
\text { Sales/Assets }\end{array}$ \\
\hline & Profitability & $\begin{array}{l}\text { Historical profitability } \\
\text { Profitability growth rate } \\
\text { Profit/Assets } \\
\text { Profit/Costs }\end{array}$ \\
\hline & Market-Data & $\begin{array}{l}\text { Volatility of stock price } \\
\text { Credit-agency rating }\end{array}$ \\
\hline \multirow{2}{*}{ Retail } & Personal Information & $\begin{array}{l}\text { Income } \\
\text { Age } \\
\text { Occupation } \\
\text { Home value } \\
\end{array}$ \\
\hline & Financial Information & $\begin{array}{l}\text { Number of loans outstanding } \\
\text { Number of credit cards } \\
\text { Balance on each card or loan } \\
\text { Any defaults in last three years }\end{array}$ \\
\hline
\end{tabular}

Adapted from Marrison (2002).

The statistical model generates an ordinal score that ranks counterparties according to their likelihood of default, or it can directly provide an unadjusted $\mathrm{PD}^{19}$. In both cases, the results of the model need to be calibrated to obtain a cycle-neutral cardinal scale. This can be done in several different ways depending on how much historical data is available. For example, the cycle neutral central tendency of the entire portfolio can be identified and used as an anchor point to adjust the PDs calculated with data from a limited part of the economic cycle.

By contrast, the market-based approaches use current market data about debt and/or equity to "back out" a market-driven measure of PD. This method was developed by Merton (1974) and popularized by the company KMV (now owned by Moody's). Merton modeled the holding of a company's debt as being equivalent to holding debt of a riskfree company plus being short a put option on the assets of the company: if the value of the assets falls below the value of the debt, the shareholders can put the company's assets to the debt holders and avoid repaying the debt, given that they are normally covered by limited liability arrangements.

The PD can be easily derived from equity prices if one assumes that market capitalization is a good proxy for the value of the firm's assets and that asset values (E) are normally distributed. On this basis, a distance to default (DD) concept can be defined as:

${ }^{19}$ Since both point-in-time and historical information is included, the PD is unadjusted in the sense that the data may not appropriately cover an entire economic cycle. An adjusted PD represents an economic cycleneutral estimate which can be conceptualized as the average PD during the entire cycle. 


$$
D D=\frac{E-D}{\sigma_{E}}
$$

where $\mathrm{D}$ is the expected future level of debt and $\sigma_{\mathrm{E}}$ is the observed volatility of asset prices. If E drops below D, the company would default and, assuming that the company's value is normally distributed, the PD is equal to the area under the curve (see Figure 2).

Figure 2: Calculation of PD using the Merton Model

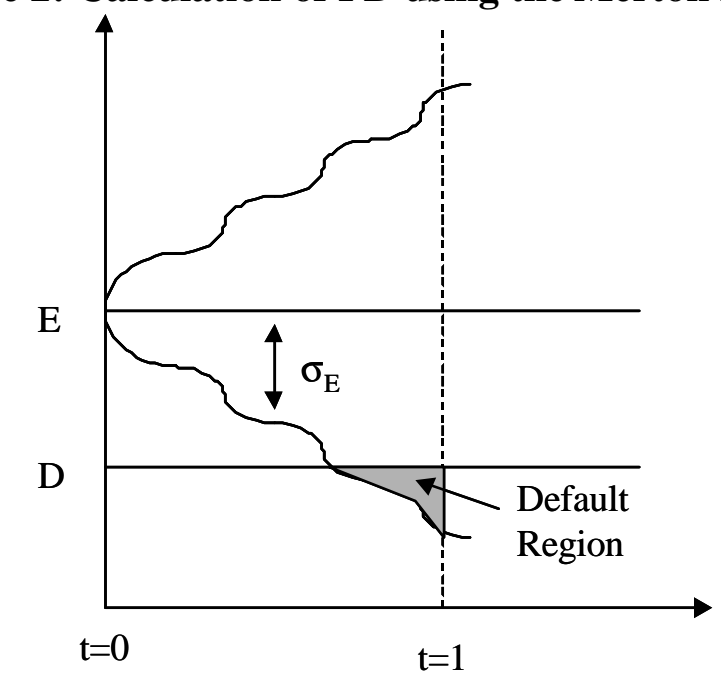

Adapted from Saunders (1999)

Similar models exist that use bond or credit default swap prices to derive a PD assuming 'risk neutral' pricing, i.e. whereby the value of a risky bond (its face value discounted at its risk-adjusted discount rate) is equal to its expected value in the future discounted at the risk-free rate. However, "backing-out" the PD from bond spreads has several problems, such as the fact that the spreads also include an implied LGD figure, implying that PD can only be uniquely determined if we already know LGD.

The main disadvantages of market-based methods are the following:

- they can only be used for publicly traded borrowers in well-functioning markets

- they tend to be 'black boxes' whose outcomes can often lack intuition

- they often lead to highly volatile levels of PD and capital.

On the other hand, the continuous market information updates (when they exist) often make these methods more reliable than those based on historical accounting data, which are only updated periodically or with a $\operatorname{lag}^{20}$. As a result, the two methodologies tend to co-exist within sophisticated banks and be primarily used for different types of credit exposures. However, in the case of non-corporate loans and for banks in most emerging economies, the empirical method is often the only realistic option.

\footnotetext{
${ }^{20}$ For example, one can compare the (slow) adjustment of Enron's official credit ratings prior to default with those that were provided by market-based models.
} 


\section{Exposure at Default $(E A D)$}

EAD refers to the outstanding amount at the time of default. In the simple case of a loan, the exposure is assumed to be fixed for each year and can be derived from the agreed amortization plan. In the case of derivatives, it requires more complex simulations to estimate the path that the underlying value of the asset may take and thus the potential future exposure that would arise ${ }^{21}$.

In the case of lines of credits or any other type of revolving facility, EAD is generally estimated using empirical data by looking at the distribution of utilization levels of credit lines prior to the moment of default, as expressed in the following equation:

$$
\text { ExposureatDefault }=\text { CurrentExposure }+ \text { LEF } \times \text { UnutilisedPortionof theLimit }
$$

LEF is the Loan Equivalency Factor and represents the portion of the unutilized line that is expected to be drawn down before default (see Figure 3). Generally, a "race to default" takes place whereby lines are quickly drawn down shortly before default. Most empirical studies indicate that the counterparty's facility type and pre-default credit grade are good LEF predictors. Counterparties that default despite having a good credit rating generally default due to an unforeseen 'disaster' (e.g. fraud) and have less time to draw down credit lines, as opposed to counterparties that have been slowly downgraded and will increasingly utilize their credit lines.

Figure 3: Estimation of LEF and EAD

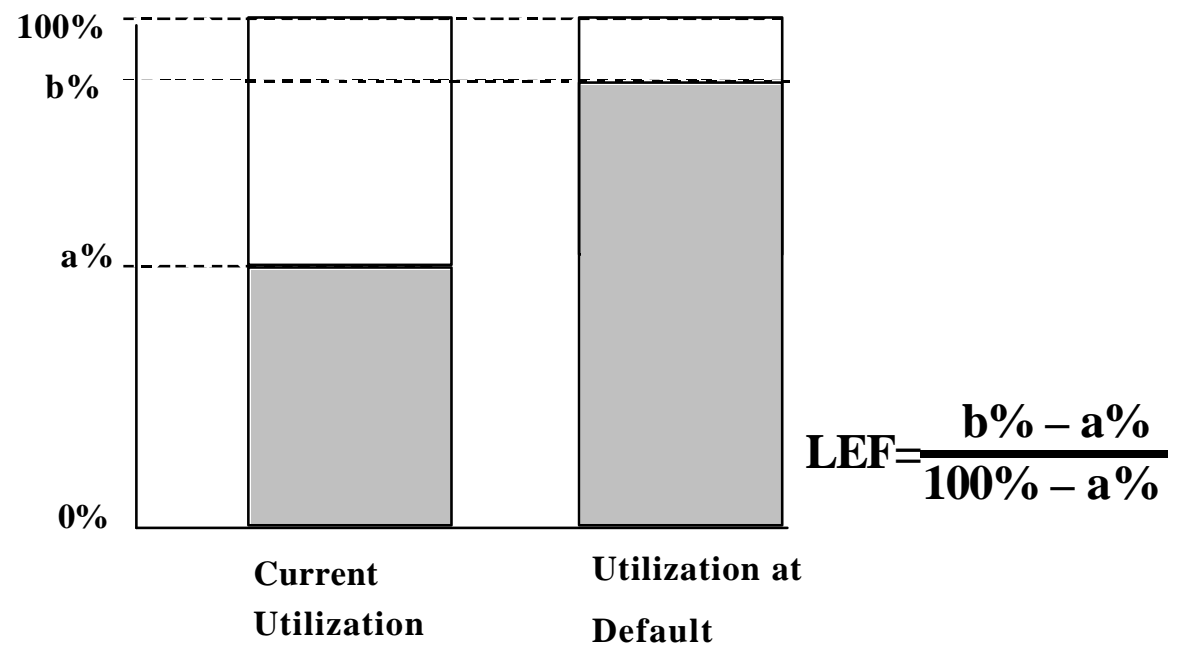

\footnotetext{
${ }^{21}$ The current mark-to-market (MTM) value of a derivative is effectively a probability weighted average of all future possible values, both negative and positive. By contrast, Potential Future Exposure for credit risk calculations is the probability weighted average of only future positive MTM values, replacing all future negative MTM values by zero. This leads to a truncation of the probability distribution of future MTM values, which shifts its mean to the right.
} 


\section{Loss Given Default (LGD)}

LGD is the percentage of the EAD that is lost in the event of a default ${ }^{22}$. Its calculation requires answering the following questions:

- How much is recovered and from where (e.g. collateral liquidation)?

- How long did it take to recover and what is the financial cost (i.e. interest income forgone) associated with this period of time?

- How much had to be spent in the recovery process (i.e. workout expenses)?

There are three main types of LGD measurement ${ }^{23}$. The first one (workout LGD) is based on the estimation and timing of cash flows and costs from the workout process:

$$
L G D=\frac{E A D-\text { Recovery }+A d \min }{E A D}
$$

For the estimation to be accurate, all figures must be expressed in present value terms to take into account time effects since the recovery process can be very long. Recovery refers to the present value of the total recovered amount and is a function of the country (legal regime, court efficiency and insolvency proceedings), loan seniority, industry and collateral presence (type, amount etc.). Admin includes all the related workout costs that were incurred (e.g. legal and collection fees). Workout LGD is by far the most common approach in the case of most loan types, particularly for a bank that has sufficient historical loss experience with these variables. The level of sophistication in its LGD calculation varies from a single look-up table with a few values to an advanced econometric model or neural network with several causal variables.

The second type of LGD measurement (market LGD) can be observed from market prices and trades of defaulted bonds or loans after the actual default event. In the exceptional case that a liquid distressed debt market exists, LGD can be written as:

$$
L G D=\frac{\text { ValueBefore }- \text { ValueAfter }}{\text { ValueBefore }}
$$

where Value refers to the valuation before and after (i.e. sale price, reflecting the market's expected present value of eventual recovery) the time of default. Because these transactions take place at arm's length, they are less subject to potential valuation problems. Most rating agency recovery studies are based on this approach.

Finally, the third type of LGD measurement (implied market LGD) is derived from the prices of fixed income and credit derivatives products using a theoretical asset-pricing model. This approach essentially 'backs out' LGD from the credit spreads of risky (but not defaulted) bonds or from credit default swap prices, but it is limited in scope (traded

\footnotetext{
${ }^{22}$ Until Basel II formalized the use of LGD, this concept was also called Severity.

23 See Schuermann T. (March 2003) for a detailed description.
} 
debt only) and subject to methodological problems (credit spread also reflects PD and potentially a liquidity premium, tax considerations etc.).

\section{Unexpected Loss (UL) for a Single Loan}

UL is simply the volatility in the components of EL that were described above:

$$
U L=\sigma(E L)=\sigma(P D \times E A D \times L G D)
$$

In order to solve this equation, it would be necessary to know the standard deviation of all three variables. In the case of PD, since it reflects an underlying Bernoulli variable (i.e. a variable than can only have two states - the counterparty defaults or not), its standard deviation is equal to:

$$
\sigma(P D)=P D(1-P D)
$$

Some practitioners also assume that the variance of EAD and LGD is zero ${ }^{24}$. As a result, the UL equation for a single loan (what is often referred to as the 'stand-alone UL') is often simplified as follows:

$$
U L=\sqrt{E L(E A D \times L G D-E L)}
$$

\section{Portfolio- and Bank-Level UL}

The most important point of departure between traditional bottom up (i.e. loan-by-loan) and modern credit analysis is the treatment of portfolio-level effects that derive from correlations (both within and across portfolios). Unlike EL, the bank- or portfolio-level $\mathrm{UL}$ is not equal to the sum of individual ULs; that is because variance is not an additive parameter, but depends critically on the loss correlations between all the loans in the portfolio. A highly correlated portfolio implies a more skewed loss distribution and would require, ceteris paribus, a higher level of capital than a more diversified portfolio ${ }^{25}$. That has a major implication for credit risk management: an individual loan's marginal contribution to portfolio credit risk (referred to as the loan's 'contributory UL' to distinguish it from 'stand-alone UL') critically depends on the properties of the portfolio in which it is held.

The $E L$ for a portfolio $p$ with $N$ loans is simply the sum of the $E L$ for each loan:

$$
E L_{P}=\sum_{i=1}^{N} E L_{i}
$$

\footnotetext{
${ }^{24}$ In the case of EAD, the justification for this assumption is that we are referring to a normal term loan whose EAD is fixed at 1 . In the case of LGD, however, the assumption does not hold well because LGD has often empirically exhibited a binomial distribution and has tended to vary over the business cycle.

${ }^{25}$ In intuitive terms, a highly correlated portfolio contains loans that tend to default together more often, thereby exacerbating credit losses experienced during bad times. Such a portfolio would exhibit a loss distribution with a much longer tail implying that, for the same EL, its UL would be much greater.
} 
However, the portfolio $U L$ must explicitly take account of intra-portfolio correlations:

$$
U L_{P}^{2}=\sum_{i=1}^{N} \sum_{j=1}^{N} \rho_{i, j} U L U L_{j}
$$

where $\rho_{i, j}$ is the pair-wise correlation between loans $\mathrm{i}$ and $\mathrm{j}$. A correlation of 1 would imply that when one defaults the other one does too simultaneously. A correlation of 0 means that they tend to default completely independently of each other. For practical purposes, loss correlation is often simplified to default correlation, which is used to measure the extent to which counterparties tend to default simultaneously.

The methods of analysis used to calculate these correlations are beyond the scope of this document, but a common simplifying assumption is to define a single $\rho$ for a portfolio with a specific country, industry and/or rating profile (e.g. US investment grade telecom exposures). This default correlation can be calculated in a credit portfolio model by observing asset correlation movements (i.e. stock prices) of relevant public companies, or through direct observation of historical data, a method more amenable to retail portfolios that have large default datasets. Making this assumption, the $U L_{P}$ simplifies to:

$$
U L_{P}=\sqrt{\rho} \sum_{i=1}^{N} U L_{i}
$$

Since a typical bank contains several credit portfolios (each with a different $\rho$ ), deriving the bank-wide UL is a complex calculation consisting of the individual $U L_{P}$ and a correlation matrix between the different portfolios (i.e. inter-portfolio correlations).

The above discussion has used a frequent, albeit incorrect, simplifying assumption that all portfolios are infinitely granular, i.e. no single portfolio exposure accounts for more than an arbitrarily small share of the total. In reality, many portfolios tend to be 'lumpy' (i.e. made up of fewer relatively large loans), which implies that idiosyncratic risk is not diversified away completely and that capital estimates based only on systematic risk factors are understated. In that situation, an add-on granularity factor needs to be added to the correlations that give rise to portfolio-level diversification effects.

\section{Portfolio Loss Distribution and Economic Capital}

The aforementioned building blocks allow the estimation of the mean (EL) and variance (UL) of credit losses, but the shape of the entire portfolio-level loss distribution is still not known. There are two main ways of deriving it: the closed-form and the simulation/value-at-risk approach. The former simply imposes a specific distributional assumption (e.g. beta distribution) to replicate what has been observed empirically, while the latter uses a Monte Carlo simulation to explicitly construct a portfolio loss distribution. Numerous commercial credit value-at-risk models have been developed in the last 10-15 years (e.g. CreditMetrics, KMV, CreditRisk+) that use the main credit risk inputs described above to derive a loss distribution, by assuming that correlations across borrowers arise due to common dependence on a set of 'systematic risk factors' (essentially variables representing the state of the economy). Sophisticated banks typically use these models nowadays for active portfolio-level credit management 
(particularly for large corporate loans) by identifying risk concentrations and opportunities for diversification via debt instruments and credit derivatives.

Once the bank-level credit loss distribution is constructed, credit economic capital is simply determined by the bank's tolerance for credit risk, i.e. the bank needs to decide how much capital it wants to hold in order to avoid insolvency because of unexpected credit losses over the next year. A safer bank must have sufficient capital to withstand losses that are larger and more rare, i.e. they extend further out in the loss distribution tail. In practice, therefore, the choice of confidence interval in the loss distribution corresponds to the bank's target credit rating (and related default probability) for its own debt. For example, a bank that wants its public debt to be rated AA needs (based on historical default rates of AA rated companies) to hold enough capital to have a $99.97 \%$ survival probability over a one-year time horizon. As Figure 4 shows, economic capital is the difference between EL and the selected confidence interval at the tail of the loss distribution; it is equal to a multiple $\mathrm{K}$ (often referred to as the capital multiplier) of the standard deviation of EL (i.e. UL).

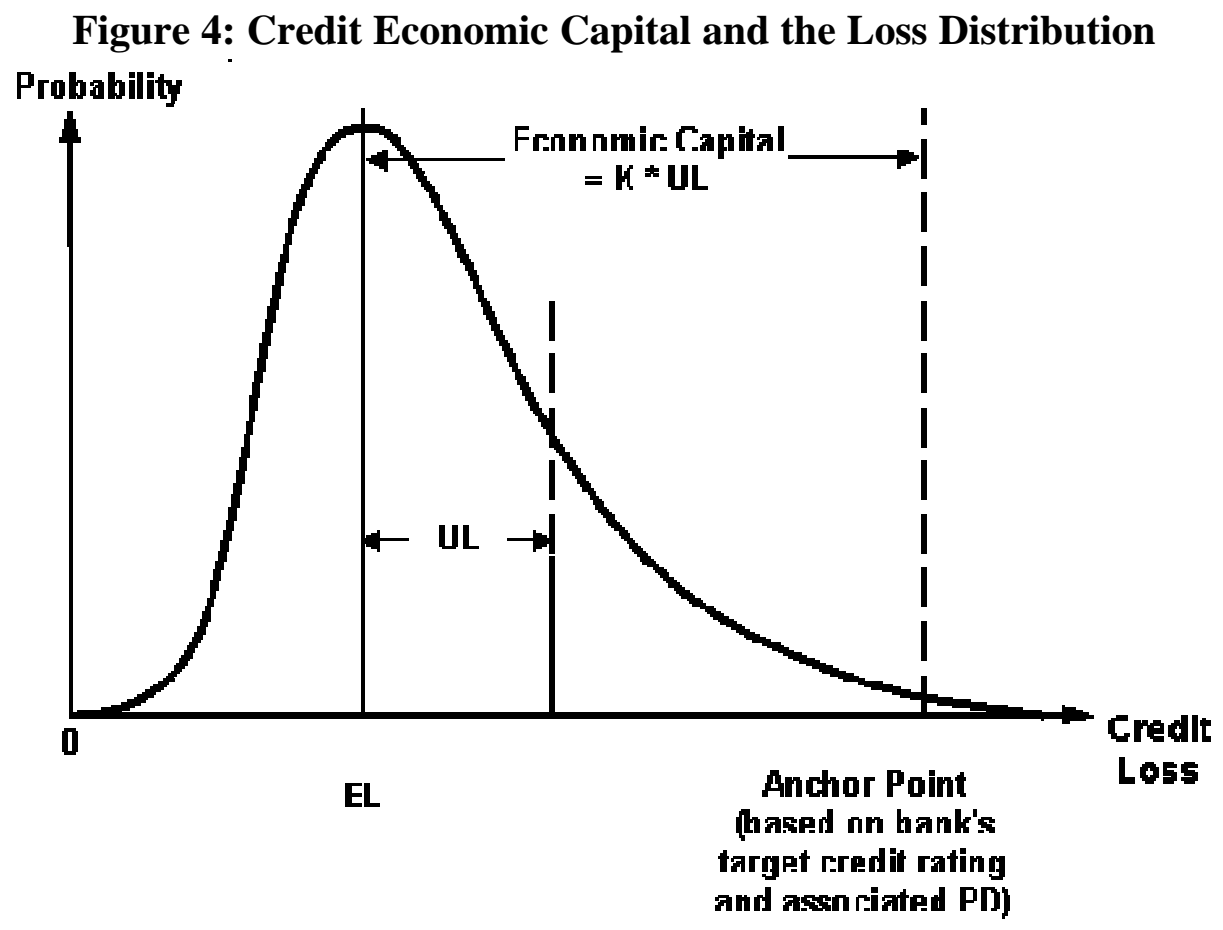

The shape of the loss distribution can vary considerably depending on product type and borrower credit quality. For example, high quality (low PD) borrowers tend to have proportionally less EL per unit of capital charged, meaning that $\mathrm{K}$ is higher and the shape of their loss distribution is more skewed (and vice versa).

The loss distribution and associated economic capital can be calculated at various levels within the organization, although the desired confidence interval (level of protection) must be applied consistently. At a bank-wide level, the capital adequacy of the institution (once credit capital is combined with capital for other risk types) can be evaluated by 
comparing required economic capital with available financial resources. At a business unit level, capital consumption can be used as an input in the unit's RAROC or Shareholder Value Added (SVA) ${ }^{26}$ calculations. At a transaction level, it can be used to correctly price the risk undertaken. It is worth noting that different assumptions about diversification benefits need to be made at each of these levels. For example, when capital is calculated for a business unit or a transaction, it can be on a stand-alone basis or on a contributory basis. In the first case, the business unit or the transaction is seen as disconnected from the rest of the bank and does not therefore gain any of the diversification benefits that come as a result of being part of a bigger institution ${ }^{27}$. In the second case, credit risk correlations with the rest of the bank exposures (and therefore additional diversification benefits) are taken into account.

\section{EL and Economic Capital Versus Provisions and Regulatory Capital}

EL and economic capital for credit risk are conceptually (if not explicitly) comparable to loan loss provisions and regulatory capital. Although the latter two variables also attempt to estimate the amount of expected and unexpected credit losses respectively, their methodologies are much cruder and fraught with problems. In particular, loan loss provisions are primarily based on a combination of country-specific regulatory, tax and accounting considerations; these drive a wedge between statistically driven EL and actual provisions, since the latter are generally based on the concept of incurred losses ${ }^{28}$. By comparison, EL and economic capital come from different parts of the same loss distribution and are therefore consistent with each other. As will be seen in the next section, Basel II aligns regulatory capital for credit risk much closer to economic capital, which also has implications for the relation between EL and loan loss provisions.

\footnotetext{
${ }^{26}$ An SVA or EVA (Economic Value Added) framework attempts to measure the economic value added/profit of a business line (or of the entire bank) by using a target hurdle rate to adjust the accounting profit so that it includes the opportunity cost of the economic capital that is needed to support that business. ${ }^{27}$ In intuitive terms, the credit capital of a loan to a US corporate would not include the diversification benefits of (lower correlated) loans to UK mortgages, even though the bank might be active in both business lines. Particularly when RAROC is used to measure the performance of individual business units, economic capital is typically calculated without such diversification benefits.

28 This inconsistency of treatment is currently being discussed between the Basel Committee and the International Accounting Standards Board (IASB).
} 


\section{Credit Risk Framework under Basel II $^{29}$}

In contrast to Basel I that applies a "one size fits all" approach to all banks, Basel II offers a menu of options under Pillar 1 for calculating the credit capital requirements of banking book exposures ${ }^{30}$. In particular, two main methodologies can be used for most exposures: the Standardized Approach and the Internal Ratings Based (IRB) Approach; securitization exposures are subject to a separate (but similar) capital treatment. Each approach has different characteristics and requirements that are briefly described below.

\section{Standardized Approach}

This approach measures credit risk similar to Basel I, but has greater risk sensitivity because it uses the credit ratings of external credit assessment institutions (ECAIs) to define the weights used when calculating RWAs. National supervisors are responsible for recognizing ECAIs in accordance with specific eligibility criteria (e.g. objectivity, independence, disclosure of methodologies etc.) mentioned in the document, as well as for mapping their assessments to the risk weights available.

Table 2: Risk Weights Under the Standardized Approach for Credit Risk

\begin{tabular}{|c|c|c|c|c|c|c|c|}
\hline Type of Claim & $\begin{array}{c}\text { AAA to } \\
\text { AA - }\end{array}$ & $\begin{array}{c}\text { A+ to } \\
\text { A- }\end{array}$ & $\begin{array}{r}\text { BBB+ } \\
\text { to BBB - }\end{array}$ & \multicolumn{2}{|c|}{$\begin{array}{c}\text { BB+ to } \\
\text { B- }\end{array}$} & $\begin{array}{c}\text { Below } \\
\text { B- }\end{array}$ & Unrated \\
\hline Sovereigns \& Central Banks* & $0 \%$ & $20 \%$ & $50 \%$ & \multicolumn{2}{|c|}{$100 \%$} & $150 \%$ & $100 \%$ \\
\hline $\begin{array}{c}\text { Banks - Option } 1 \text { (based on sovereign } \\
\text { treatment by supervisors) }\end{array}$ & $20 \%$ & $50 \%$ & $100 \%$ & \multicolumn{2}{|c|}{$100 \%$} & $150 \%$ & $100 \%$ \\
\hline $\begin{array}{c}\text { Banks - Option } 2 \text { (based on rating from } \\
\text { ECAI) for longer-term claims }\end{array}$ & $20 \%$ & $50 \%$ & $50 \%$ & \multicolumn{2}{|c|}{$100 \%$} & $150 \%$ & $50 \%$ \\
\hline $\begin{array}{c}\text { Banks - Option } 2 \text { (based on rating from } \\
\text { ECAI) for short-term } * * \text { claims }\end{array}$ & $20 \%$ & $20 \%$ & $20 \%$ & \multicolumn{2}{|c|}{$50 \%$} & $150 \%$ & $20 \%$ \\
\hline Corporates (incl. insurance companies) & $20 \%$ & $50 \%$ & \multicolumn{2}{|c|}{$\begin{array}{l}100 \%(\mathrm{BBB}+ \\
\text { to } \mathrm{BB}-)\end{array}$} & & $\begin{array}{l}150 \% \\
\text { elow BB-) }\end{array}$ & $100 \%$ \\
\hline Regulatory retail portfolios $* * *$ & \multicolumn{7}{|c|}{$75 \%$} \\
\hline Secured by residential property & \multicolumn{7}{|c|}{$35 \%$} \\
\hline Secured by commercial real estate & \multicolumn{7}{|c|}{$100 \%$ (lower risk weight allowed under strict conditions) } \\
\hline $\begin{array}{c}\text { Past due loans (unsecured portions net } \\
\text { of specific provisions) }\end{array}$ & \multicolumn{7}{|c|}{$100 \%$ or $150 \%$ (depending on degree of provisions coverage) } \\
\hline All other assets & \multicolumn{7}{|c|}{ at least $100 \%$} \\
\hline
\end{tabular}

Source: Basel Committee on Banking Supervision (June 2004).

Note 1: Claims to non-central government public sector entities can be treated either as claims on banks or the relevant sovereign

Note 2: Off-Balance Sheet items will be converted to credit exposure equivalents using credit conversion factors

* As an alternative to ECAI ratings, the country risk scores assigned by Export Credit Agencies (ECAs) recognized by national supervisors, or the consensus risk scores published by the OECD in the "Arrangements on Guidelines for Officially Supported External Credits", may be used. To qualify, an ECA must publish its risk scores and subscribe to the OECD-agreed methodology.

** Short-term claims must have an original maturity of three months or less.

*** In order to qualify, claims must meet criteria relating to orientation, product, g ranularity and low value of individual exposures.

\footnotetext{
${ }^{29}$ See Basel Committee of Banking Supervision (June 2004) for a comprehensive and detailed description of the framework.

${ }^{30}$ There is also a counterparty credit risk capital charge for over-the-counter derivatives, repo-style and other transactions booked in the trading book, separate from the capital charge for general market risk and specific risk. The risk weights to be used must be consistent with those used for calculating the capital requirements in the banking book (i.e. Standardized or IRB Approaches).
} 
Table 2 illustrates the risk weights by type of counterparty and credit rating. However, considerable national discretion exists - for example, supervisors may:

- select a lower risk weight to apply to banks' exposures to their sovereign (and by implication to other domestic banks under Option 1 below) as long as the exposure is in domestic currency and funded in that currency

- permit banks to risk weight all corporate claims at $100 \%$ irrespective of the existence of external ratings

- apply higher risk weights for regulatory retail, unrated corporate claims etc.

Credit risk mitigants are recognized for regulatory capital purposes as long as:

- General requirements for legal certainty are satisfied (e.g. the enforceability of master netting agreements)

- Mitigants are not double counted (i.e. not already reflected in an issue-specific rating used to determine risk weights)

- Remaining residual risks are properly accounted for

- Minimum conditions relating to collateral treatment are observed.

Banks may opt either for the simple approach (i.e. substitute risk weight of collateral for the risk weighting of the counterparty), or for the comprehensive approach (i.e. estimate volatility-adjusted amounts for both exposure and collateral) to credit risk mitigation. Although the latter approach recognizes more collateral instruments as eligible mitigants, it also imposes supplementary criteria depending on whether banks use standard supervisory haircuts or their own estimates/VAR models to calculate market price and foreign exchange volatility. Additional operational requirements are also necessary for the recognition of guarantees and credit derivatives as risk mitigants.

In order to provide additional guidance for smaller systems/less sophisticated supervisors, the Basel Committee has collected the simplest available options for calculating riskweighted assets (including securitization exposures) under a so-called "Simplified Standardized Approach". It is expected that bank supervisors from many developing countries will (at least initially) adopt this simpler version of the Standardized Approach.

\section{IRB Approach}

The IRB Approach is a more sophisticated methodology, since it is primarily based upon the credit risk building blocks described in the previous section. Subject to certain minimum conditions and disclosure requirements, this approach relies on banks' own internal estimates of certain risk parameters to determine credit capital requirements. However, the capital figure itself is still derived from a supervisory formula provided by the Basel Committee that has been calibrated to reflect the risk of specific asset types and to ensure that overall capital levels in G-10 countries remain broadly unchanged.

Under the IRB Approach, all banking book exposures must be categorized into broad asset classes using specific definitions and criteria provided by the Committee. For each of these asset classes, there are distinct: 
- Risk components - estimates of risk parameters (PD, LGD, EAD, effective maturity) that can be calculated by banks themselves or provided by supervisors

- Risk-weight functions - the formulas by which risk components are transformed into risk-weighted assets and therefore capital requirements

- Minimum requirements - minimum standards for a bank to use the IRB approach for a given asset class.

For corporate, sovereign and bank exposures, the RWAs are calculated as follows:

$$
\begin{aligned}
& \text { Correlation }(\rho)=0.12 \times \frac{1-e^{-50 \times P D}}{1-e^{-50}}+0.24 \times\left[1-\frac{1-e^{-50 \times P D}}{1-e^{-50}}\right] \\
& \text { Maturity Adjustment }(b)=(0.11852-0.05478 \times \ln (P D))^{2} \\
& \text { Capital Requirement }(K)=\left[L G D \times \Phi\left[\frac{\Phi^{-1}(P D)}{\sqrt{ }(1-\rho)}+\sqrt{\frac{\rho}{1-\rho}} \times \Phi^{-1}(0.999)\right]-P D \times L G D\right] \times \frac{1+(M-2.5) \times b}{1-1.5 \times b} \\
& \qquad \text { Risk-weighted assets }(R W A)=K \times 12.5 \times E A D \\
& \text { where: Capital charge }=8 \% \times R W A \\
& \Phi-1(\mathrm{z}) \text { is the inverse cumulative distribution function (c.d.f.) for a standard normal } \\
& \text { random variable, i.e. the value of y such that } \Phi(\mathrm{y})=\mathrm{z} \\
& \Phi(\mathrm{y}) \text { is the c.d.f. for a standard normal random variable } \\
& \ln (\mathrm{PD}) \text { is the natural logarithm of the PD } \\
& \mathrm{M} \text { is effective (remaining) maturity }
\end{aligned}
$$

Although the capital formula appears rather daunting and unintuitive ${ }^{31}$, it is worth highlighting some of its main characteristics:

- A loss correlation is included but modeled solely as a function of PD, thereby ignoring (or at least moving to Pillar II) potentially important portfolio characteristics such as industry and geographic diversification ${ }^{32}$

\footnotetext{
${ }^{31}$ See Wilde (May 2001) and Gordy (October 2002) for a technical, and Fitch Ratings (August 2004) for a non-technical, description of the formula. Formally speaking, the formula is based on a one-factor model, meaning that there is only one systematic factor (as a proxy for general economic conditions) that drives correlations across borrowers. This is important because (together with the infinite granularity assumption) it gives rise to additive, portfolio-invariant contributions to capital, i.e. the IRB capital requirements only depend on each individual loan's own characteristics and do not have to be calibrated for each portfolio based on its particular composition.

${ }^{32}$ Formulas for other asset classes differ in their approach to these parameters, but a common characteristic is that lower quality (higher PD) assets have lower correlations. This corresponds to the empirical finding that lower quality exposures are driven mainly by idiosyncratic (borrower-specific) factors and thus relatively less by broader market events (systematic risk).
} 
- A maturity adjustment is introduced to reflect the potential credit quality (PD) deterioration of loans with longer maturities. The average portfolio effective maturity is 'anchored' at 2.5 years; exposures with effective maturities beyond that time period are penalized (and vice versa)

- The portfolio is assumed to be infinitely granular, effectively treating potential portfolio concentrations (geographic, industry, borrower) as a Pillar 2 issue

- The risk weights are calibrated so that a bank has sufficient capital to cover unexpected credit losses with a probability of $99.9 \%$ over a one-year horizon ${ }^{33}$, which corresponds approximately to a target solvency level (credit rating) of A-.

In addition, the formula explicitly distinguishes between UL and EL, with the risk weight functions producing capital requirements only for the former portion. Under the IRB approach, banks will need to compare the amount of total eligible provisions (both general and specific provisions, excluding those for securitization and equity exposures) with total estimated EL. When the latter exceeds the former, banks must deduct the difference from regulatory capital; when the former exceeds the latter, banks may recognize the difference (up to a limit) in Tier 2 capital.

Figure 5 below shows how sensitive (especially compared to Basel I) the resulting IRB capital charge is to a corporate borrower's credit rating/PD. As can be deduced, loans to highly rated corporates are expected to benefit from Basel II (in terms of incurring a lower capital charge), while low rated loans will be significantly penalized.

\section{Figure 5: Comparison of Capital Requirements under Different Basel Approaches ${ }^{34}$}

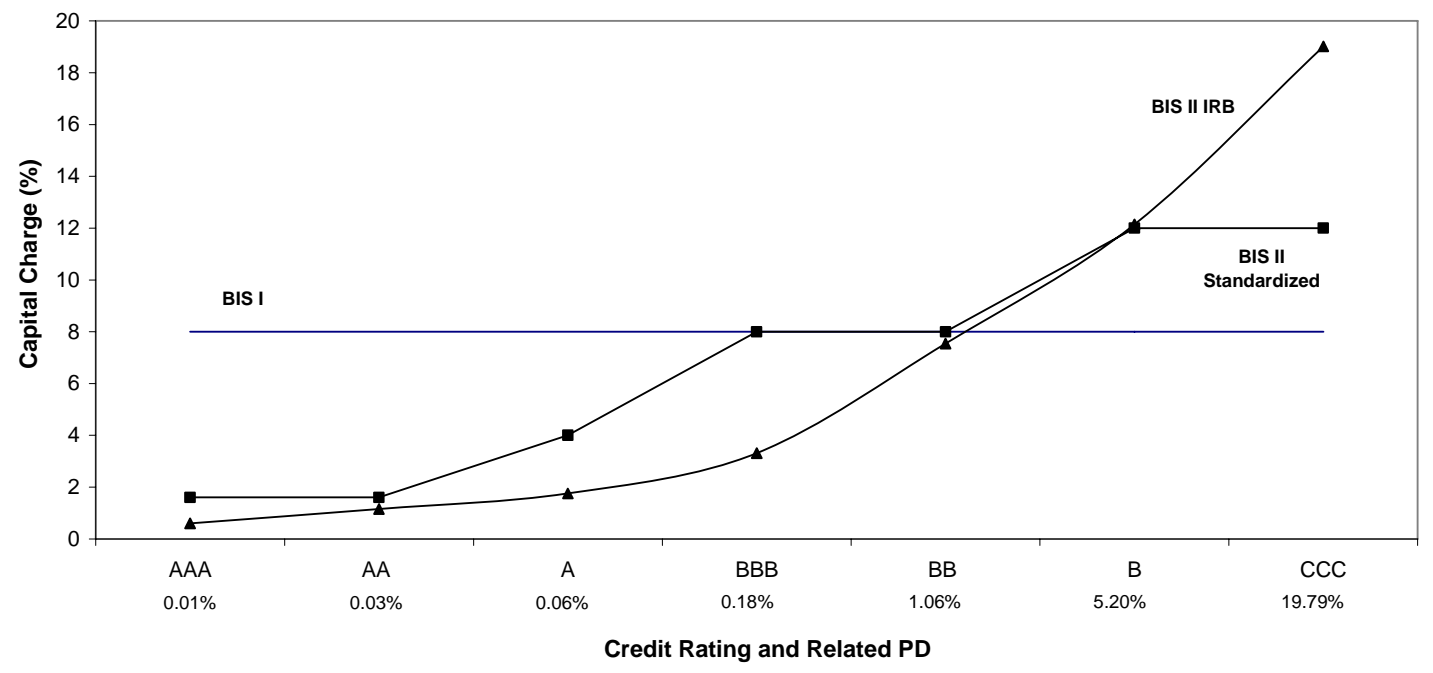

\footnotetext{
${ }^{33}$ This effectively corresponds to a one in 1,000 chance that the bank's credit losses over the next year will exceed the regulatory minimum capital.

${ }^{34}$ Uses IRB formula for corporate exposures and assumes an LGD of 45\%, an EAD of $100 \%$ and effective maturity of 2.5 years. The calibrations of credit ratings to PDs are taken from published default rates for unsecured senior debt by Standard and Poors.
} 
Most asset classes can be treated under one of two approaches: Foundation or Advanced IRB (see Table 3 below). Under the former, banks generally provide their own PD estimates and rely on supervisory estimates for other risk components ${ }^{35}$. Under the latter, banks provide their own estimates for most/all (depending on the asset class) risk components, subject to meeting minimum standards. However, the same risk-weight functions by asset class must be used for both approaches to derive capital requirements.

Once a bank adopts an IRB Approach for part of its holdings, it is expected to extend it across the entire banking group via a phased rollout. The bank's implementation plan must specify the extent and timing of the roll-out, and must be agreed with the supervisors. Some exposures in non-significant business units and asset classes (or subclasses in the case of retail) that are deemed immaterial may be exempt from the requirements subject to supervisory approval; these will follow the Standardized Approach for determining capital requirements. Once the bank has adopted an IRB Approach, it is expected to continue to use it - a voluntary return to another approach is permitted only in extraordinary circumstances and must be approved by the supervisor.

To be eligible for the IRB Approach, banks must demonstrate to their supervisors that they meet certain minimum requirements at the outset and on an on-going basis. These requirements apply (with some exceptions) across all asset classes and IRB approaches, and are summarized in Table 4 below. However, during the three-year transition period following implementation of the framework, a few specific requirements ${ }^{36}$ can be relaxed subject to supervisory discretion.

\footnotetext{
${ }^{35}$ For example, under the IRB Foundation Approach, senior and subordinate claims on corporates, sovereigns and banks are assigned an LGD of $45 \%$ and $75 \%$ respectively, while the effective maturity for corporate exposures is 2.5 years. The comprehensive formula for credit risk mitigation also applies.

${ }^{36}$ For example, the minimum five year period to collect data for PD estimation for corporate, sovereign and bank exposures, as well as the minimum three year period to demonstrate the use of a rating system that is broadly in line with minimum requirements for corporate, bank, sovereign and retail exposures.
} 


\section{Table 3: Classification and Treatment of Exposures under the IRB Approach}

\begin{tabular}{|c|c|c|c|}
\hline $\begin{array}{c}\text { Asset } \\
\text { Classes } \\
\end{array}$ & $\begin{array}{c}\text { Asset Sub-Classes / } \\
\text { Categories } \\
\end{array}$ & IRB Approach & Formula for Risk-Weighted Assets \\
\hline \multirow{4}{*}{ Corporate } & Standard corporate & Foundation or Advanced & Corporate formula \\
\hline & SMEs & Foundation or Advanced & $\begin{array}{l}\text { Corporate formula with firm-size } \\
\text { adjustment }\end{array}$ \\
\hline & $\begin{array}{l}\text { Eligible purchased } \\
\text { receivables }\end{array}$ & Foundation or Advanced & $\begin{array}{l}\text { Corporate formula with different (top- } \\
\text { down) procedure for deriving PD and } \\
\text { LGD; firm-size adjustment might also } \\
\text { apply; additional adjustment in } \\
\text { formula to account for dilution risk }\end{array}$ \\
\hline & $\begin{array}{l}\text { Specialized Lending } \\
\text { (project finance, object } \\
\text { finance, commodities } \\
\text { finance, income- } \\
\text { producing real estate, } \\
\text { high-volatility } \\
\text { commercial real estate) }\end{array}$ & $\begin{array}{c}\text { 'Supervisory slotting } \\
\text { criteria' or Foundation or } \\
\text { Advanced }\end{array}$ & $\begin{array}{l}\text { Separate formula for 'supervisory } \\
\text { slotting criteria' approach; Corporate } \\
\text { formula for Foundation or Advanced } \\
\text { Approach; adjustments to both } \\
\text { formulas for high-volatility } \\
\text { commercial real estate exposures }\end{array}$ \\
\hline Sovereign & N/A & Foundation or Advanced & Same as Corporate formula \\
\hline Bank & N/A & Foundation or Advanced & Same as Corporate formula \\
\hline \multirow{4}{*}{ Retail* } & $\begin{array}{l}\text { Secured by residential } \\
\text { property (e.g. } \\
\text { residential mortgages) }\end{array}$ & $\begin{array}{l}\text { No distinction (only one } \\
\text { approach) }\end{array}$ & $\begin{array}{l}\text { Separate formula for residential } \\
\text { mortgage exposures }\end{array}$ \\
\hline & $\begin{array}{l}\text { Qualifying revolving } \\
\text { retail (e.g. credit cards) }\end{array}$ & $\begin{array}{l}\text { No distinction (only one } \\
\text { approach) }\end{array}$ & $\begin{array}{l}\text { Separate formula for qualifying } \\
\text { revolving retail exposures }\end{array}$ \\
\hline & $\begin{array}{l}\text { All other retail } \\
\text { exposures (e.g. } \\
\text { consumer loans) }\end{array}$ & $\begin{array}{l}\text { No distinction (only one } \\
\text { approach) }\end{array}$ & $\begin{array}{l}\text { Separate formula for other retail } \\
\text { exposures }\end{array}$ \\
\hline & $\begin{array}{l}\text { Eligible purchased } \\
\text { receivables }\end{array}$ & $\begin{array}{l}\text { No distinction (only one } \\
\text { approach) }\end{array}$ & $\begin{array}{l}\text { One of the three Retail formulas, } \\
\text { depending on composition of } \\
\text { receivables; Retail formula with } \\
\text { highest capital requirements to be used } \\
\text { for hybrid (mixed) pools; adjustment } \\
\text { to selected formula to account for } \\
\text { dilution risk }\end{array}$ \\
\hline Equity** & N/A & Market-based or PD/LGD & $\begin{array}{l}\text { Two distinct formulas for market- } \\
\text { based approach (simple risk weight or } \\
\text { internal models method); separate } \\
\text { formula for PD/LGD approach }\end{array}$ \\
\hline
\end{tabular}


Table 4: Minimum Requirements for IRB Approach

\begin{tabular}{|c|c|}
\hline Dimensions & Key Minimum Requirements \\
\hline Rating system design & $\begin{array}{l}\text { - Separate borrower creditworthiness and transaction-specific dimensions } \\
\text { - } \quad \text { Meaningful distribution of exposures across grades } \\
\text { - Plausible, consistent and detailed rating definitions, processes and criteria for } \\
\text { assigning exposures to grades within a rating system } \\
\text { - Written documentation of rating system design, default and loss definitions etc. }\end{array}$ \\
\hline $\begin{array}{l}\text { Risk rating system } \\
\text { operations }\end{array}$ & $\begin{array}{l}\text { - } \quad \text { Independence of rating assignment process } \\
\text { - } \\
\text { - } \\
\text { - }\end{array}$ \\
\hline $\begin{array}{l}\text { Corporate governance } \\
\text { and oversight }\end{array}$ & $\begin{array}{l}\text { - All material aspects of rating and estimation processes to be approved by senior } \\
\text { management and (all or a subset of) the Board of Directors } \\
\text { Independent credit risk control unit responsible for design/selection, } \\
\text { implementation and performance of internal rating systems } \\
\text { - Internal audit (or an equally independent function) to review the rating system } \\
\text { and the credit function's operations at least annually }\end{array}$ \\
\hline Use of internal ratings & $\begin{array}{l}\text { - Internal ratings and default/loss estimates to play an essential role in credit } \\
\text { approval, risk management, internal capital allocation and corporate governance } \\
\text { Rating system broadly in line with minimum requirements for at least three } \\
\text { years prior to qualification }\end{array}$ \\
\hline Risk quantification & $\begin{array}{l}\text { - PD estimates must be long-run average of one-year default rates (except for } \\
\text { retail exposures) and must be based on at least a five-year observation period } \\
\text { Internal estimates must reflect all relevant, material and available data, and } \\
\text { must be grounded in historical experience and empirical evidence } \\
\text { - } \quad \text { Specific reference definition of default and indications of inability to pay } \\
\text { LGD and EAD estimation should incorporate cyclical variability when } \\
\text { important for certain types of exposures, and must be based on a minimum data } \\
\text { observation period of at least seven years (five for retail exposures) } \\
\text { The risk-mitigating effect of guarantees and single-name credit derivatives can } \\
\text { be used to adjust own estimates of PD or LGD, but the adjusted risk weight } \\
\text { cannot be lower than that of a comparable, direct exposure to the guarantor } \\
\text { Minimum requirements (legal certainty, effective ness of monitoring, control } \\
\text { and work-out systems, compliance with internal policies and procedures) for } \\
\text { eligible purchased receivables making use of the top-down treatment of default } \\
\text { risk and/or IRB treatment of dilution risk }\end{array}$ \\
\hline $\begin{array}{l}\text { Validation of internal } \\
\text { estimates }\end{array}$ & $\begin{array}{l}\text { - Systems to periodically validate and document the accuracy and consistency of } \\
\text { rating systems, processes and the estimation of all relevant risk components }\end{array}$ \\
\hline $\begin{array}{l}\text { Supervisory LGD and } \\
\text { EAD estimates }\end{array}$ & $\begin{array}{l}\text { Minimum operational and risk management requirements for recognition of } \\
\text { additional (to those eligible under the Standardized Approach) collateral types, } \\
\text { including leases }\end{array}$ \\
\hline $\begin{array}{l}\text { Calculation of capital } \\
\text { charges for equity } \\
\quad \text { exposures }\end{array}$ & $\begin{array}{l}\text { Quantitative and qualitative minimum requirements (capital charge and risk } \\
\text { quantification, risk management process and controls, validation and } \\
\text { documentation) to be eligible for the internal models market-based approach }\end{array}$ \\
\hline $\begin{array}{l}\text { Disclosure } \\
\text { requirements }\end{array}$ & - Banks must meet the disclosure requirements of Pillar 3 \\
\hline
\end{tabular}

Source: Basel Committee on Banking Supervision (June 2004). 


\section{Securitizations}

The Basel Committee introduces a separate securitization framework that aims to align regulatory capital treatment to the actual credit risk incurred by such exposures. Banks must apply the framework for determining regulatory capital requirements on exposures that arise from traditional or synthetic securitizations ${ }^{37}$, or similar structures that contain features common to both. Given the multitude of ways in which securitizations may be structured, their eligibility and related capital treatment must be determined on the basis of economic substance rather than legal form ${ }^{38}$. An originating bank may exclude (nonretained) securitized exposures from the calculation of risk-weighted assets only if specific operational requirements that ensure true and complete risk transfer are fulfilled.

The framework includes a Standardized and an IRB Approach for securitization exposures, depending on the method by which the underlying exposures are treated. The former approach applies ECAI assessments that are generally mapped to risk weights, with specific treatment applied to unrated securitization exposures, credit risk mitigants and early amortization features. The latter approach utilizes three different methods to derive regulatory capital requirements:

- Ratings-Based Approach (RBA) for rated exposures, or where a rating can be inferred (subject to specific operational requirements); the risk weights depend on the external/inferred rating, whether the rating is long- or short-term, the granularity of the underlying pool and the seniority of the position

- Internal Assessment Approach for asset-backed commercial paper-related exposures such as liquidity facilities and credit enhancements; banks can use (subject to specific operational requirements) the ir internal credit assessments of such exposures, which must be mapped to equivalent external credit rating agency ratings in order to determine the appropriate RBA risk weights to use

- Supervisory Formula in all other instances; this is based on five bank-supplied inputs (IRB capital charge had the underlying exposures not been securitized, the tranche's credit enhancement level and thickness, and the pool's effective number of exposures and weighted average LGD).

For a bank using the IRB Approach, the maximum capital requirement for its securitization exposures is equal to the IRB capital requirement that would have been assessed against the underlying exposures had they not been securitized.

\footnotetext{
${ }^{37}$ A traditional securitization is a structure where the cash flow from an underlying pool of exposures is used to service at least two different stratified risk positions ("tranches") reflecting different degrees of credit risk (subordination). Payments to the investor depend upon the performance of the specified underlying exposures (as opposed to being derived from an obligation of the entity originating those exposures) and the type of tranche held. A synthetic securitization shares the same structure as a traditional securitization, but it transfers (in whole or in part) the credit risk of an underlying pool of exposures via the use of credit derivatives or guarantees that serve to hedge the risk of the portfolio.

${ }^{38}$ Examples of securitization exposures in this context include direct investments in (or retention of) assetbacked and mortgage-backed securities, as well as the provision of explicit (e.g. credit enhancements) or implicit (e.g. liquidity facilities) support to a securitization transaction.
} 


\section{Pillars 2 and $3^{39}$}

The aims of the supervisory review process of the Basel II framework (Second Pillar) are twofold: to ensure that banks have adequate capital to support all their risks ${ }^{40}$, and to encourage them to develop and use better risk management techniques. Four key principles of supervisory review are identified by the Basel Committee to complement existing best-practice supervisory guidance such as the Basel Core Principles (BCP). Special emphasis is placed on internal controls and risk management processes as additional (to capital) means of addressing bank risks. Another important aspect of this Pillar is the assessment of compliance with the minimum standards and disclosure requirements of the more advanced methods in Pillar 1, such as the IRB Approach for credit risk.

Three main areas are mentioned as being particularly suited to treatment under Pillar 2:

- Risks considered under, but not fully captured by, the Pillar 1 process - for example, credit concentration risk

- Factors not taken into account by Pillar 1 - for example, liquidity risk, interest rate risk in the banking book, business and strategic risks

- Factors external to the bank - for example, business cycle effects.

Although little specific guidance is currently provided for these areas beyond what has already been previously published by the Basel Committee, there is substantial built-in flexibility to incorporate new technical/practical developments going forward.

Pillar 3 develops a set of qualitative and quantitative disclosure requirements to allow market participants to assess, in a consistent and comparable manner, key pieces of information on the institution's capital adequacy. The aim is to complement the other two Pillars by encouraging market discipline as a 'counterweight' to the increased discretion accorded to banks in the estimation of their own capital requirements. Disclosure requirements are either general or specific (i.e. depending on the selected approach), and include information on the scope of application, capital structure and adequacy, and risk exposure and assessment by risk type. Some of those requirements also represent qualifying criteria for the use of particular methodologies or the recognition of particular instruments or transactions in the calculation of regulatory capital.

\footnotetext{
${ }^{39}$ Since the paper focuses primarily on credit risk measurement under Basel II, the discussion of Pillars 2 and 3 issues has been intentionally kept to a minimum; interested readers should refer to the Basel Committee on Banking Supervision (June 2004) for more details.

${ }^{40}$ Bank management continues to bear primary responsibility for the capital adequacy assessment process, which is comprised of the following features: board and senior management oversight, sound capital assessment, comprehensive assessment of risks, monitoring and reporting, and internal control review.
} 


\section{Implementation Challenges and Policy Implications for Developing Countries}

Basel II represents a significant (albeit incomplete ${ }^{41}$ ) improvement in the risk sensitivity of capital regulation, and its risk weights are calibrated to provide banks with incentives, in terms of capital reduction, to migrate toward more advanced risk management approaches. The revised Accord presents a fairly complex 'menu of options' that allows great discretion to bank supervisors ${ }^{42}$. Even though the framework is mandatory only for internationally active banks domiciled in G-10 countries and/or European Union members, it has effectively become a global standard. In a recent survey ${ }^{43}$, more than 88 non-Basel Committee jurisdictions worldwide have declared their intention to adopt Basel II within the first few years of its implementation. Even in those cases where "intention" may actually amount to wishful thinking without considering the implications or difficulties of such a move, it is true that bank supervisors worldwide are being faced with pressures to migrate in the direction of Basel II. Two of the major drivers for this are the significant presence of foreign-controlled banks whose home supervisors are already moving to Basel II adoption, as well as the desire to be perceived as compliant with international best practice (peer pressure).

A number of private sector reports ${ }^{44}$, as well as the Basel Committee's own Quantitative Impact Studies (QIS), have attempted to identify and quantify the potential impact from Basel II implementation on national banking systems. With a few exceptions ${ }^{45}$, most surveys focus primarily on G-10 countries and generally ignore potential repercussions that are more applicable to, or critical for, developing countries. What follows below is an attempt to identify some of the credit risk-related implementation challenges that are of particular relevance to these countries and derive suitable policy implications ${ }^{46}$.

\section{Key Implementation Issues}

Credit risk-related implementation challenges for developing countries can be conceptually separated into general and specific: the former represent broad Basel II-

\footnotetext{
${ }^{41}$ In particular, the framework has a number of deficiencies: it continues to use book (as opposed to market-based) values, its treatment of correlations is inadequate (especially the assumption of perfect correlation across portfolios and risk types, implying that they need to be simply summed up), it is too prescriptive in defining the formulae for measuring credit risk under the IRB Approach, it ignores problems arising from the definition/quality of regulatory capital, while it only indirectly addresses other important risk types (e.g. interest rate risk in the banking book) via Pillar 2.

${ }^{42}$ See Basel Committee on Banking Supervision (July 2004) for a summary of areas of national discretion.

${ }^{43}$ See Financial Stability Institute (July 2004).

${ }^{44}$ For example, see Mercer Oliver Wyman (December 2003 and May 2004).

${ }^{45}$ See Powell A. (March 2002, September 2004) and Majnoni G., Miller M. and Powell A. (October 2004).

${ }^{46}$ Although not discussed in the paper, there is also currently an active policy debate (particularly in Latin America) on key systemic risks that characterize developing countries, which often manifest themselves in real exchange rate-induced (currency mismatches in debtor balance sheets, particularly in dollarized economies) and real interest-rate induced (duration mismatches in debtor balance sheets) credit risk. Proposals on appropriate prudential responses have tended to include changes to capital rules that are not addressed under Basel II; see, for example, Ize A. and Powell A. (April 2004), Chapter 6 of the InterAmerican Development Bank (2004), and de la Torre A. and Schmukler S. L. (forthcoming).
} 
related issues that are common across all risk types and approaches, while the latter depend on the specific approach used to measure credit risk capital requirements.

Perhaps the most important general implementation challenge concerns the scope of application and required preconditions. In particular, the meaningful adoption of Basel II requires the upgrading of the supporting financial infrastructure that reaches well beyond banking supervision and encompasses the participation of a broad set of institutions that play a role in the smooth functioning of the financial system ${ }^{47}$. For example, some of the requirements under Pillar 2 (e.g. prompt corrective action, legal mandate to impose higher capital requirements, consolidated supervision etc.) and 3 (e.g. confidentiality rules) are currently beyond the reach of many supervisory authorities and require changes to a country's legal and judicial framework. In addition, the development of a credit ratings industry requires, inter alia, a reporting and corporate governance framework for companies, strong accounting and external auditing rules, the existence of credit bureaus as well as the collection and sharing of borrowers' data. The calculation of LGD also highlights the necessity for a collateral registry and the upgrading of the insolvency regime for contract enforcement and collateral execution. These requirements clearly go beyond the realm of banking supervisor responsibilities and enforcement powers.

Moreover, Basel II (particularly in its IRB form) implies fundamental changes to the way that many developing country banks are actually managed. The Accord effectively forces those banks (and their regulators) to play "catch up" with credit risk concepts and measurement tools that have long been used in more developed banking systems. In particular, the use of concepts such as economic capital and RAROC allow senior bank management to measure performance under a common metric and meaningfully compare different businesses in a better way than traditional measures (such as ROE) that fail to explicitly take risk into consideration. At a business unit level, these tools simplify the process of credit analysis, lower the subjectivity in the loan approval process and provide guidance for risk-adjusted pricing. Given their inherent complexity and required change in incentives, it will take time to embed these concepts in banks that have historically been managed on different metrics.

Other general challenges of Basel II from a developing country perspective are:

- Cost of implementation. Even though a cost-benefit assessment of the framework's implementation will vary by country, the operational requirements (especially for the IRB Approach) will likely be prohibitively expensive for many smaller developing countries. Large international banks are already closer to the adoption of Basel II-compatible risk management systems and can spread the costs over a larger asset base. Supervisors will need to decide between trying to maintain a level playing field by keeping all banks on a less advanced capital standard, or allowing some banks to adopt the IRB Approach ${ }^{48}$.

\footnotetext{
${ }^{47}$ In fact, the broad scope and nature of requirements under Pillars 2 and 3 will likely prove more useful in the long term than the complex capital rules of Pillar 1.

${ }^{48}$ For example, the US bank supervisory agencies have publicly stated their intention to ignore the Standardized and IRB Foundation approaches, and only require large, complex banks ('core group') to
} 
- Inadequate supervisory capacity. The greater burden and wide discretion placed on them by Pillars 1 (e.g. model validation) and 2 (e.g. treatment of other risks) will stretch scarce supervisory resources and will require a step-up improvement in available skills and information technology. In addition, regulators must have the ability to carry out ex-ante impact analysis before rule issuance, which represents a substantial change from an environment that has traditionally been compliance-driven. Even when supervisors build up required skills, it is likely that many of them will be poached by domestic banks that are eager to adopt these new risk management tools and able to provide them with higher salaries an unfortunate consequence of the fact that regulators often drive (rather than respond to) change in many developing countries.

- Impact on domestic banking systems is not fully understood. The multiplicity of approaches places a de facto end to the notion of a level playing field among banks under the same regulatory jurisdiction. Firstly, there will likely be a redistribution of capital requirements within and across banks depending on their individual customer, product, and portfolio mixes; the dislocation in bank behavior that may result from this redistribution has not generally been sufficiently studied or considered. Secondly, smaller domestic banks will likely be at a competitive disadvantage since they will only afford to adopt less sophisticated (and more capitalonerous) approaches to credit risk and will probably be subject to moral hazard (attracting riskier assets) because of their inability to properly differentiate and price for risk. Thirdly, to the extent that they are not already operating under an economic capital framework, a few less sophisticated foreign banks may cut back/refocus their exposures to some developing countries in response to the revised capital requirements ${ }^{49}$.

- Home-host supervisory coordination. Given the significant presence of G-10 banks in developing countries and the considerable discretion given to national supervisory authorities, a significant degree of home-host cooperation is essential to ensure consistency across jurisdictions. This cooperation must address a fundamental asymmetry of incentives: since the local subsidiary or branch is usually small compared to the overall size of the international bank but oftentimes large relative to the rest of the domestic banking system, materiality (as well as resource) considerations might discourage the home country supervisor from monitoring risks in the bank's activities in the host country, practically deferring to the host rules. A dual treatment with separate guidelines would lead the bank having to comply with the more onerous of the two requirements and would lead to inefficient duplication. Alternatively, a concerted approach could be established whereby the two regulators agree on a single set of supervisory

adopt the IRB Advanced Approach. All other banks would remain under the existing Basel I rules (perhaps with some risk weight modifications), although it is worth noting that those institutions are already subject to a comprehensive risk-based supervision process and considerable disclosure requirements. A number of large banks outside the core group have also expressed their intention to 'opt in' to Basel II.

${ }^{49}$ For example, see Hayes S., Saporta V. and Lodge D. (December 2002), and Powell A. (March 2002). 
arrangements that satisfies both home and host requirements. Consultations on developing a framework to facilitate closer practical cooperation among supervisors are currently taking place in several Basel Committee working groups, the most important of which are the Accord Implementation Group (AIG) and the Core Principles Liaison Group (CPLG) ${ }^{50}$.

- Ineffective Pillar 3. Aside from the broader issue of the relevance of specific disclosures for market participants, this Pillar is not a very useful discipline device in countries with small private markets or few incentives for creditors to monitor banks (e.g. due to presence of implicit public guarantees). In addition, the Pillar might be inapplicable in those countries whose systems are dominated by foreign banks, since the latter will likely have entered by purchasing and delisting the domestic institution. Since those banks are not obliged to publicly disclose information for their operations in such jurisdictions (unless requested by the domestic authorities), there is little market transparency or discipline.

Specific Standardized Approach-related challenges for developing countries are:

- Considerable and perhaps excessive supervisory discretion. Given the substantial discretion given to supervisory authorities in the Standardized and the Simplified Standardized Approach, it is highly likely that many will opt for maintaining the 'painless' status quo in which there is little relation of capital requirements to risk. In particular, this would imply that sovereign exposures will continue to be riskweighted at $0 \%$, which (together with the valuation of such debt at face value) has encouraged excessive sovereign lending by domestic banks to the detriment of private sector lending and financial intermediation in many developing countries.

- Little experience with ECAIs. There is a low ratings penetration in most developing countries, which tends to be corporations concentrated in a few large corporates. The sample of counterparties that are rated is also biased to the extent that only companies with higher creditworthiness tend to seek external ratings ${ }^{51}$. These two facts, combined with the likely adoption of a Simplified Standardized Approach by many developing countries, would result in little meaningful change to (or redistribution of) capital requirements compared to Basel I. Finally, the ECAIs industry in developing countries is only now being developed, so there is little local experience with its proper functioning and regulation ${ }^{52}$.

\footnotetext{
${ }^{50}$ Supervisory guidance on cross -border cooperation is described in Basel Committee on Banking Supervision (August 2003). The home-host supervisory tensions are evident in the EU debate on the division of supervisory responsibilities in the forthcoming Capital Requirements Directive that seeks to transpose Basel II into EU law.

${ }^{51}$ In particular, since unrated corporates will continue to have an $8 \%$ capital charge (as opposed to a higher charge if they are rated below BB-) provides them with perverse incentives to avoid a credit rating.

52 The situation is beginning to change in a few of the larger and more advanced middle-income countries for example, Moody's has developed a ratings model for middle market corporates in Mexico. In addition, Chile has a fairly well developed ratings industry and ratings penetration because of the regulatory requirement by institutional investors (mostly pension funds) to only invest in domestic corporates when they have been assigned a credit rating by at least two ECAIs.
} 
Finally, specific IRB Approach-related challenges for developing countries are:

- Unavailability of required risk data in easily accessible or comprehensive format. Historical loss data is required to calculate the main IRB risk parameters; that data are frequently incomplete/unavailable (i.e. not required to be collected in the past) or prohibitively expensive to collect (i.e. not in electronic format). Particularly for the development of rating systems and LGD parameters, individual banks may not have a meaningful loss dataset to enable them to build the required models and back-test their performance. In such an environment, it is essential to tackle the root causes of this problem (e.g. legal or cultural factors impeding loss data collection and sharing) prior to proceeding with Basel II adoption.

- Potentially excessive capital requirements due to inappropriate calibration. Perhaps the most fundamental IRB implementation issue for developing countries is the manner in which supervisory authorities will trade off and reconcile increased risk sensitivity with the desire to maintain aggregate capital requirements. The current calibration of the supervisory formulas is primarily based on survey data (including three QIS rounds) and model results from G-10 banks, and reflects the Committee's stated objective of broadly maintaining aggregate capital requirements. However, the selected solvency level implicit in the formulas (99.9\%, corresponding to a credit rating of A) is uniform for all banks irrespective of their country of origin. This level is inappropriately high for banks in lowly-rated countries, and may result (based on historical loss data used to calibrate the risk parameters) in excessively high IRB capital requirements. It therefore remains an open question whether the current calibration will provide enough incentives (in terms of capital reduction) for such banks and their supervisors to migrate from the Standardized to the IRB Approach.

\section{Policy Implications}

The ultimate choice of what capital standard to adopt will be made by national authorities, and it is likely several developing countries will seek to adopt Basel II as early as possible. The World Bank and the IMF have publicly stated their desire to support countries preparing for the decision of whether, when and how to implement Basel II. However, both institutions emphasize that Basel I remains a viable option in the foreseeable future, and that Basel II must be built on a solid foundation (as exemplified by compliance with key codes and standards ${ }^{53}$ ) of sound accounting and governance standards, realistic valuation rules and loan classification and provisioning practices, effective legal and judicial systems, and adequate supervisory resources and powers.

\footnotetext{
53 The most important of these are the Basel Core Principles; the core principles that are deemed most relevant to Basel II are 6 (capital adequacy), 8 (loan evaluation and provisioning), 11 (country risk), 12 (market risk), 13 (comprehensive/other risk management), 20 (consolidated supervision), 21 (information/accounting requirements) and 22 (remedial powers). Other international codes and standards include the Reports on the Observation of Standards and Codes (ROSC) on Corporate Governance, Accounting and Auditing, Bank Insolvency and Resolution, Corporate Insolvency and Creditor Rights.
} 
In the absence of a sound foundation, countries that want to proceed with Basel II implementation need to incorporate improvements in their financial infrastructure as part of a robust (and potentially long-term) Basel II roadmap. An effective and realistic roadmap can be created starting from a low base, although it should be adapted to the specific needs of the country, be realistic as to the implementation time horizon, and focus (at least in its early stages) on getting the basics of a credit risk-based supervision framework in place, namely:

- Improvement in risk management practices of the banking system. This implies an assessment of current business and risk management practices domestically and encouragement of best practice, particularly in terms of the risk governance framework (e.g. bank senior management and Board involvement, functional independence between origination and risk evaluation, appropriate reporting and loss data collection, adoption of risk-adjusted performance measures etc.).

- Training and development of a new supervisory culture. Basel II will oblige bank supervisors to learn new risk measurement and management techniques but, even more importantly, will necessitate a change in culture from one of "compliance verification" to one of "risk assessment". This will have important knock-on effects on the way that supervisors understand and conduct their business (e.g. on supervisory independence, enforcement, resources and compensation), as well as on their internal organization and staffing.

- Upgrading of financial infrastructure. The foundations of the financial system (i.e. accounting and governance standards, legal and judicial systems, contract enforcement practices) must be strengthened in order to move to Basel II. New infrastructure may also need to be developed during this process, such as the creation of credit bureaus, collateral registries, loss data consortia and ECAIs.

Finally, developing countries will need to resort to creative solutions to address some of the aforementioned weaknesses, such as the incorporation of debtor data from nonfinancial institutions, partnerships with local academic institutions to launch risk management training courses, or the obligatory pooling of loss data and the use of public credit registers for calculating risk parameters in smaller or less advanced banking systems ${ }^{54}$. If implemented correctly, Basel II has the potential to significantly improve credit risk measurement and management practices in developing countries, and thereby contribute to the effectiveness and stability of their financial systems.

\footnotetext{
${ }^{54}$ For example, see Artigas C. T. (September 2004), Majnoni G., Miller M. and Powell A. (October 2004) and Powell A., Mylenko N., Miller M. and Majnoni G. (November 2004). Powell A. (September 2004) suggests the use of a centralized ratings-based approach (CRB) as an intermediate step between the Standardized and the IRB Approaches for more sophisticated developing countries. The CRB involves the creation of a centralized rating scale, with each rating mapped to a PD, that all banks would use in order to rate their borrowers. This would allow bank supervisors to check the consistency of bank ratings across the same borrower, and thereby monitor and control the sufficiency of bank capital in relation to credit risk.
} 


\section{References}

Araten M, Jacobs M, Varshney P (May 2004), "Measuring LGD on Commercial Loans: An 18-Year Internal Study", The RAM Journal

Artigas C. T. (September 2004), "A Review of Credit Registers and their Use for Basel II", Financial Stability Institute 2004 Winning Paper, Bank for International Settlements

Basel Committee on Banking Supervision (July 1988), "International Convergence of Capital Measurement and Capital Standards", Bank for International Settlements

Basel Committee on Banking Supervision (January 1996), "Amendment to the Capital Accord to Incorporate Market Risks", Bank for International Settlements

Basel Committee on Banking Supervision (August 2003), "High-level principles for the cross-border implementation of the new Accord", Bank for International Settlements

Basel Committee on Banking Supervision (June 2004), "International Convergence of Capital Measurement and Capital Standards: A Revised Framework", Bank for International Settlements

Basel Committee on Banking Supervision (July 2004), "Implementation of Basel II: Practical Considerations", Bank for International Settlements

de la Torre A. and Schmukler S. L. (forthcoming), "Coping with Risk Through Mismatches: Domestic and International Financial Contracts for Emerging Economies", International Finance

Financial Stability Institute (July 2004), "Implementation of the new capital adequacy framework in non-Basel Committee member countries", Occasional Paper 4, Bank for International Settlements

Finger C. (April 1999), “Conditional Approaches for CreditMetrics Portfolio Distributions", CreditMetrics Monitor

Fitch Ratings (August 2004), "Demystifying Basel II: A Closer Look at the IRB Measures and Disclosure Framework", Fitch Ratings Special Report

Global Risk Regulator (various issues), found at www.globalriskregulator.com

Gordy M (October 2002), "A Risk-Factor Model Foundation for Ratings-Based Bank Capital Rules", Board of Governors of the Federal Reserve System 
Hayes S., Saporta V. and Lodge D. (December 2002), "The impact of the new Basel Accord on the supply of capital to emerging market economies", Bank of England Financial Stability Review

Inter-American Development Bank's 2005 Report on Economic and Social Progress in Latin America (2004), Unlocking Credit: The Quest for Deep and Stable Bank Lending, The Johns Hopkins University Press

Ize A. and Powell A. (April 2004), "Prudential Responses to De Facto Dollarization", IMF Working Paper 04/66

Kealhofer S. (January/February 2003), "Quantifying Credit Risk I: Default Prediction”, Financial Analysts Journal

Majnoni G., Miller M. and Powell A. (October 2004), "Bank Capital and Loan Loss Reserves under Basel II: Implications for Emerging Countries", World Bank Policy Research Working Paper 3437

Marrison C. (2002), The Fundamentals of Risk Measurement, New York: McGraw-Hill

Mercer Oliver Wyman (December 2003), "The New Rules of the Game: Strategic Implications of the Basel II Capital Accord" report

Mercer Oliver Wyman (May 2004), "Risk and Basel II: A Retail Perspective” report

Merton RC (1974), "On the Pricing of Corporate Debt: The Risk Structure of Interest Rates", Journal of Finance

Powell A. (March 2002), “A Capital Accord for Emerging Economies?”, World Bank Policy Research Working Paper 2808

Powell A. (September 2004), "Basel II and Developing Countries: Sailing Through the Sea of Standards", World Bank Policy Research Working Paper 3387

Powell A., Mylenko N., Miller M. and Majnoni G. (November 2004), "Improving Credit Information, Bank Regulation and Supervision: On the Role and Design of Public Credit Registries", World Bank Policy Research Working Paper 3443

Saunders A. S. (1999), Credit Risk Measurement, New York: John Wiley \& Sons

Schuermann T. (March 2003), "What do we know about Loss-Given-Default?", Federal Reserve Bank of New York paper

Wilde, T. (May 2001), "IRB approach explained”, Risk magazine 